\title{
Detection of human herpesvirus 7 infection in young children presenting with exanthema subitum
}

\author{
Ivna de Melo Magalhães, Rebeca Vazquez Novo Martins, Renata Oliveira Vianna, Natalia Moysés, \\ Larissa Alves Afonso, Solange Artimos Oliveira, Silvia Maria Baeta Cavalcanti/ ${ }^{+}$
}

Departamento de Microbiologia e Parasitologia, Laboratório 319, Instituto Biomédico,

Universidade Federal Fluminense, Rua Ernani Melo 101, 24210-130 Niterói, RJ, Brasil

In this study, we assessed the prevalence of human herpesvirus-7 (HHV-7) in 141 serum samples from children less than four years of age with exanthematic disease. All samples were negative for measles, rubella, dengue fever and parvovirus B19 infection. Testing for the presence of human herpesvirus-6 (HHV-6)-specific high avidity IgG antibodies by indirect immunofluorescence assay (IFA) revealed two main groups: one composed of 57 patients with recent primary HHV-6 infection and another group of 68 patients showing signs of past HHV-6 infection. Another 16 samples had indeterminate primary HHV-6 infection, by both IgG IFA and IgM IFA. Serum samples were subjected to a nested polymerase chain reaction to detect the presence of $H H V-7$ DNA. Among patients with a recent primary HHV-6 infection, HHV-7 DNA was present in $1.7 \%$ of individuals; however, $5.8 \%$ of individuals tested positive for HHV-7 DNA in the group with past primary HHV-6 infection. Among the 16 samples with indeterminate diagnosis, $25 \%$ (4/16) had HHV-7 DNA ( $p$ < 0.002). We hypothesise that HHV-7 might be the agent that causes exanthema. However, a relationship between clinical manifestations and the detection of virus DNA does not always exist. Therefore, a careful interpretation is necessary to diagnose a primary infection or a virus-associated disease. In conclusion, we detected HHV-7 DNA in young children from the state of Rio de Janeiro, Brazil.

Key words: HHV-7 - children - exanthema subitum - PCR

Human herpesvirus-7 (HHV-7) is a member of the Roseolovirus genus within the Betaherpesvirinae subfamily, which was first isolated from purified, activated $\mathrm{CD} 4^{+} \mathrm{T}$ lymphocytes from the peripheral blood of a healthy individual by Frenkel et al. (1990). HHV-7 is closely related to human herpesviruses-6 (HHV-6). Both cause infections that occur in early childhood and cause short febrile diseases and are sometimes associated with cutaneous rash [exanthema subitum (ES)]. Furthermore, HHV-7 and HHV-6 are highly prevalent in the healthy population and are known to establish latency in macrophages and T-lymphocytes. Healthy carriers also frequently shed virus in their saliva. Genetically, their nucleic acid sequence identity ranges from $20-75 \%$ in various genes and their virions share several common antigenic epitopes. These similarities have made the development of diagnostic assays challenging (Ward 2005, Caselli \& Di Luca 2007). Along with ES, HHV-7 infections have been associated with sporadic cases of pityriasis rosea, hepatitis, neurological manifestations and transplant complications (Black \& Pellett 1999).

ES is a classical rash disease of early childhood that is accompanied by the abrupt onset of a high fever that lasts three-four days; a maculopapular rash appears as

Financial support: CAPES, PROPPi-UFF (FOPESQ 010/2009)

+ Corresponding author: silviacavalcanti@vm.uff.br

Received 27 October 2010

Accepted 11 February 2011 the child's temperature falls by crisis. As hypothesised by Yamanishi et al. (1988), HHV-6B represents the primary etiological agent of ES and second exanthema episodes are caused by HHV-6 reactivation. However, HHV-7 was isolated from the peripheral blood lymphocytes (PBL) of children with ES that had a previously documented episode of HHV-6-associated ES; furthermore, examination of sera samples revealed IgG seroconversion for HHV-7 (Ueda et al. 1994). In conjunction with HHV-7 seroconversion, many primary cases also showed simultaneous increases in HHV-6 antibody titres. As multiple serological studies indicate that most children acquire HHV-6 prior to HHV-7 (Caserta et al. 1998, Black \& Pellett 1999) and Frenkel et al. (1990) showed that HHV-7 infection can reactivate HHV-6 infection, it was hypothesised that reactivated HHV-6 may be the true cause of the clinical symptoms. However, more recent studies have found seroconversion and isolated HHV-7 DNA from the PBL of children with ES symptoms that do not exhibit evidence of prior HHV-6 infection (Torigoe et al. 1995, Caserta et al. 1998). Other explanations for increased HHV-6 antibody titres during primary HHV-7 infection include immune cell stimulation by common antigenic epitopes.

Although exanthematic syndrome is well characterised, it was noted many years ago that the rash is frequently misdiagnosed as measles, rubella or dengue infection (Tait et al. 1996, Oliveira et al. 2003). Thus, primary HHV-6 and HHV-7 infection should be included in the differential diagnosis of rash illnesses in young children. As described by Black et al. (1996), nearly $10 \%$ of rash illness patients who were presumptively diagnosed with measles or rubella were seronegative for these viruses 
in laboratory assays; these patients had seroconverted for HHV-7 and were most likely experiencing primary HHV-7 infection (Black et al. 1996). HHV-6 and HHV-7 should also be ruled out during rash presentations attributed to antimicrobial sensitivity to prevent children from incorrectly being diagnosed with allergies to antibiotics. In addition, the accurate diagnosis of HHV-7 and HHV6 infections would decrease unnecessary antimicrobial prescriptions, reducing the potential for generating antibiotic-resistant microbes (Black \& Pellet 1999).

Serological methods can be used for the detection of primary HHV-7 infection; however, immunological cross-reactivity between HHV-6 and HHV-7 is well documented (Ward 2005) and HHV-7 viremia can represent either a primary or a reactivated infection (Hall et al. 2006). Currently, although a specific immunofluorescence technique is accepted as the gold standard for HHV-6 diagnosis, no commercial test is yet available to screen for HHV-7 in the general population.

HHV-7-specific nested and conventional polymerase chain reaction (PCR) primer sets for qualitative, quantitative and multiplex assays have been developed and are useful for detection of viral DNA in human tissue samples and body fluids (Ward 2005).

In this study, we used a nested technique PCR to assess the prevalence of HHV-7 in serum samples from children less than four years of age with exanthematic disease.

The study was conducted between January 1998-December 2006 at the Antônio Pedro University Hospital and a large primary health care unit in Niterói, state of Rio de Janeiro (RJ), Brazil. A total of 141 serum samples were obtained from children younger than four years old who presented with rashes. All samples tested were previously screened and were negative for measles, rubella, dengue fever and parvovirus B19 infections. All samples were also PCR negative for the presence of HHV-6 DNA, as described by Magalhães et al. (2010b). Additionally, samples were tested for the avidity of HHV-6-specific IgG antibodies by indirect immunofluorescence assay (IFA), as described by de Oliveira Vianna et al. (2008). Overall, 57 patients exhibited recent HHV-6 primary infection, defined by low antibody avidity detected by IFA. In contrast, 68 had past HHV-6 primary infection, determined by the presence of high avidity antibodies detected by IFA; thus, the patients in this group did not exhibit any agent associated with rash. The other 16 samples had indeterminate primary HHV-6 infection; in these patients, the only serum available was obtained during the acute phase and was negative HHV-6-specific antibody. In general, these samples were taken less than nine days after rash onset, at a medium of five days after fever onset. In these cases, primary infection could not be excluded by IFA (Oliveira et al. 2003). De Oliveira Vianna et al. (2008) also investigated IgM antibodies by using IFA, but no IgM positivity was detected (Biotrin Human Herpesvirus 6 IgM IFA, Biotrin, Ireland).

Informed consent was obtained from the parents or guardians of the patients. The study protocol was approved by the Hospital's Research Ethics Committee (CEP-CMM/HUAP 85/02).
To detect HHV-7 infection, DNA was extracted from $500 \mu \mathrm{L}$ of serum by using QIAmp Kit (QIAgen, Germany) and tested for HHV-7 DNA with the use of a nested PCR assay; reaction conditions and primer sets were as previously described in Magalhães et al. (2010a). Data were analysed using the EPInfo 2004 Statistical Software Package (CDC, Atlanta, EUA, 2004). Prevalence rates were compared through Chi-square tests with a Yates correction. The significance level (p) was set at 0.05 .

PCR testing revealed that of the 141 samples, nine were positive for HHV-7 DNA (6.4\%). Among the 57 samples that exhibited a recent primary HHV-6 infection, HHV-7 DNA was present in $1.7 \%$ (1/57). When we analysed the 68 samples with past primary HHV-6 infection, we observed a frequency of $5.8 \%(4 / 68)$ for the detection of HHV-7 DNA. It is interesting to note that among the 16 acute serum samples with indeterminate diagnosis, $25 \%$ $(4 / 16)$ had HHV-7 DNA $(p<0.002)$. Although no statistical correlation was observed between female and male patients for cases ( 1 male) or controls ( 2 males, 2 females), all four inconclusive samples were from male patients. However, our casuistic was too small to suggest any correlation, as has been described in the literature, associating young girls with a higher sensitivity (Ward 2005).

The frequency rates described here are lower than those previously published (Kidd et al. 1998). Our findings may have resulted from the fact that our study group was very young, mainly comprised of children less than three years of age, making it possible that these children had not been infected yet; this hypothesis was also proposed by Ward (2005). However, these results could also be attributed to the lack of standardisation of Roseolovirus diagnosis. As suggested by Black and Pellet (1999), detection of viral DNA in the serum is indicative of an active infection, but less sensitive primer pairs, low viral loads or inhibitors present in the serum could cause false negatives.

Notably, the laboratory diagnosis of HHV-6 and 7 infections is confounded by the limited availability of antibody and DNA tests, problems with antigenic cross-reaction and a lack of understanding of the clinical relevance and epidemiology of these two viruses (Ward 2005).

Regarding Roseolovirus primary infection epidemiological data, several authors have proposed that HHV-7 infection usually occurs later than HHV-6 infection (Wyatt et al. 1991, Torigoe et al. 1995, Tanaka-Taya et al. 1996, Ward et al. 2001). However, HHV-7 infection may sometimes occur earlier or as soon as infection by HHV-6 (Oliveira et al. 2003). Consistent with these findings, we examined a one-year old child with a recent HHV-6 infection and HHV-7 DNA, suggesting the occurrence of a coinfection. Such events have been previously described by Hall et al. (2006). Notably, our study population exhibited a low socio-economic status, which has been associated with early disease exposure (Ongrádi et al. 1999).

In this study, we found that $5.8 \%$ of individuals had a past primary HHV-6 infection and HHV-7 DNA. In these patients, the observed exanthema could have been caused by either HHV-7 or by HHV-6 reactivation, as previously observed by Tanaka-Taya et al. (2000) in vitro and by Frenkel and Roffman in 1996 in vivo. Although 
antibody detection tests to confirm HHV-7 seroconversion were not performed in these studies, these children were three years old or younger, suggesting that HHV-7 could be the agent causing the clinical signs (Oliveira et al. 2003). It is important to emphasise that HHV-6specific PCR was performed and that no positive cases were found (Magalhães et al. 2010b). However, although herpesvirus DNA was detected in the serum of these immunocompetent children, there is not always a relationship between clinical manifestations and the detection of virus DNA. Therefore, a careful interpretation is necessary to diagnose a primary infection or a virusassociated disease (Hara et al. 2002). Prevalence rates described here were similar between cases and controls and no statistical differences were found $(\mathrm{p}=0.52)$.

Among our samples, we detected HHV-7 DNA in 25\% of the samples with previously undetermined diagnosis. We speculate that these patients, who were negative for prior exposure to other exanthematic agents, such as rubella, measles, parvovirus B19 and dengue fever, could be presenting an exanthematic episode due to primary HHV-7 infection. This group was previously tested for HHV-6 exposure by IFA detection of IgM antibodies, but no positivity was found and they were still undetermined. In fact, IgM tests usually have low accuracy, related to serum inhibitors and cross-reactivity among herpesviruses; these issues can give rise to both false positive and false negative results (de Oliveira Vianna et al. 2008).

Although PCR detection has not been validated for the clinical diagnosis of HHV-7 infection, given the lack of proper antibody detection assays, it might be further studied as a possible tool for the differential diagnosis of exanthematic disease in young children. In conclusion, we describe HHV-7 DNA detection in young children, corroborating previous findings of HHV-7 infection in RJ.

\section{REFERENCES}

Black JB, Durigon E, Kite-Powell K, de Souza L, Curli SP, Afonso AM, Theobaldo M, Pellett PE 1996. Seroconversion to human herpesvirus 6 and human herpesvirus 7 among Brazilian children with clinical diagnoses of measles or rubella. Clin Infect Dis 23: 1156-1158.

Black JB, Pellett PE 1999. Human herpesvirus 7. Rev Med Virol 9: 245-262.

Caselli E, Di Luca D 2007. Molecular biology and clinical associations of Roseoloviruses human herpesvirus 6 and human herpesvirus 7. New Microbiol 30: 173-187.

Caserta MT, Hall CB, Schnabel K, Long CE, D’Heron N 1998. Primary human herpesvirus 7 infection: a comparison of human herpesvirus 7 and human herpesvirus 6 infections in children. J Pediatr 133: 386-389.

de Oliveira Vianna RA, Siqueira MM, Camacho LA, Setúbal S, Knowles W, Brown DW, de Oliveira SA 2008. The accuracy of anti-human herpesvirus $6 \mathrm{IgM}$ detection in children with recent primary infection. J Virol Methods 153: 273-275.

Frenkel N, Roffman E 1996. Human herpesvirus 7. In BN Fields, DM Knipe, PM Howley, RM Chanock, TP Monath, JL Melnick, B Roizman, SE Straus (eds.), Fields virology, 3rd ed., Lippincott Williams \& Wilkins, Philadelphia, p. 2609-2622.
Frenkel N, Schirmer EC, Wyatt LS, Katsafanas G, Roffman E, Danovich RM, June CH 1990. Isolation of a new herpesvirus from human CD4 ${ }^{+}$T cells. Proc Natl Acad Sci USA 87: 748-752.

Hall CB, Caserta MT, Schnabel KC, McDermott MP, Lofthus GK, Carnahan JA, Gilbert LM, Dewhurst S 2006. Characteristics and acquisition of human herpesvirus (HHV) 7 infections in relation to infection with HHV-6. J Infect Dis 193: 1063-1069.

Hara S, Kimura H, Hoshino Y, Tanaka N, Nishikawa K, Ihira M, Yoshikawa T, Morishima T 2002. Detection of herpesvirus DNA in the serum of immunocompetent children. Microbiol Immunol 46: 177-180.

Kidd IM, Clark DA, Bremner JA, Pillay D, Griffiths PD, Emery VC 1998. A multiplex PCR assay for the simultaneous detection of human herpesvirus 6 and human herpesvirus 7, with typing of HHV-6 by enzyme cleavage of PCR products. J Virol Methods 70: 29-36.

Magalhães IM, Martins RVN, Cossatis JJ, Cavaliere RM, Afonso LA, Moysés N, Oliveira SA, Cavalcanti SMB 2010a. Detection of human herpesvirus 6 and 7 DNA in saliva from healthy adults from Rio de Janeiro, Brazil. Mem Inst Oswaldo Cruz 105: 925-927.

Magalhães IM, Martins RVN, Vianna RO, Oliveira SA, Cavalcanti SMB 2010b. Diagnosis of human herpesvirus 6B primary infection by the polymerase chain reaction in young children with exanthematic disease. Rev Soc Bras Med Trop, in press.

Oliveira SA, Turner DJ, Knowles W, Nascimento JP, Brown DW, Ward KN 2003. Primary human herpesvirus- 6 and -7 infections, often coinciding, misdiagnosed as measles in children from a tropical region of Brazil. Epidemiol Infect 131: 873-879.

Ongrádi J, Csiszár A, Maródi CL, Sólyom J, Horváth A, Menezes J 1999. Presence of antibodies to human herpesvirus type 6 and 7 in Hungarian children. Orv Hetil 140: 935-940.

Tait DR, Ward KN, Brown DW, Miller E 1996. Exanthem subitum (roseola infantum) misdiagnosed as measles or rubella. BMJ 312: 101-102.

Tanaka-Taya K, Kondo T, Mukai T, Miyoshi H, Yamamoto Y, Okada S, Yamanishi K 1996. Seroepidemiological study of human herpesvirus- 6 and -7 in children of different ages and detection of these two viruses in throat swabs by polymerase chain reaction. J Med Virol 48: 88-94.

Tanaka-Taya K, Kondo T, Nakagawa N, Inagi R, Miyoshi H, Sunagawa T, Okada S, Yamanishi K 2000. Reactivation of human herpesvirus 6 by infection of human herpesvirus 7. J Med Virol 60: 284-289.

Torigoe S, Kumamoto T, Koide W, Taya K, Yamanishi K 1995. Clinical manifestations associated with human herpesvirus 7 infection. Arch Dis Child 72: 518-519.

Ueda K, Kusuhara K, Okada K, Miyazaki C, Hidaka Y, Tokugawa K, Yamanishi K 1994. Primary human herpesvirus 7 infection and exanthema subitum. Pediatr Infect Dis J 13: 167-168.

Ward KN 2005. The natural history and laboratory diagnosis of human herpesviruses- 6 and -7 infections in the immunocompetent. J Clin Virol 32: 183-193.

Ward KN, Turner DJ, Parada XC, Thiruchelvam AD 2001. Use of immunoglobulin $\mathrm{G}$ antibody avidity for differentiation of primary human herpesvirus 6 and 7 infections. J Clin Microbiol 39: 959-963.

Wyatt LS, Rodriguez WJ, Balachandran N, Frenkel N 1991. Human herpesvirus 7: antigenic properties and prevalence in children and adults. $J$ Virol 65: 6260-6265.

Yamanishi K, Okuno T, Shiraki K, Takahashi M, Kondo T, Asano Y, Kurata T 1988. Identification of human herpesvirus- 6 as a causal agent for exanthem subitum. Lancet 1: 1065-1067. 
List of 326 contigs identified from the expression library generated from oenocytes of Aedes aegypti pupae

\begin{tabular}{|c|c|c|c|c|c|c|c|}
\hline Contig & $\mathrm{n}$ & vs. Ae. aegypti Liverpool strain transcripts & e & $\begin{array}{l}\text { vs. Liverpool strain } \\
\text { genomic supercontigs }\end{array}$ & $\begin{array}{l}\text { vs. Anopheles } \\
\text { gambiae }\end{array}$ & $\begin{array}{l}\text { vs. Drosophila } \\
\text { melanogaster }\end{array}$ & Function \\
\hline 1 & 32 & AAEL008802-RA conserved hypothetical protein & e-142 & - & AGAP012571 & - & \\
\hline 2 & 10 & AAEL008802-RA conserved hypothetical protein & e-143 & - & AGAP012571 & - & \\
\hline 3 & 16 & AAEL006824-RA cytochrome P450 & 0 & - & AGAP000877 & CG3972 & \\
\hline 4 & 5 & AAEL008802-RA conserved hypothetical protein & $4 e-69$ & - & AGAP012571 & - & \\
\hline 5 & 2 & AAEL008802-RA conserved hypothetical protein & $5 e-53$ & - & AGAP012571 & - & \\
\hline 6 & 14 & AAEL004851-RA hypothetical protein & 1e-99 & - & - & - & \\
\hline 8 & 12 & AAEL004054-RA cytochrome P450 & 0 & - & AGAP001076 & CG11715 & \\
\hline 9 & 10 & AAEL002204-RA fatty acid synthase & 0 & - & AGAP008468 & CG17374 & Esterase/lipase/thioesterase \\
\hline 10 & 8 & AAEL003942-RA 60S ribosomal protein L44 L41, putative & e-174 & - & AGAP003538 & CG7424 & \\
\hline 11 & 5 & AAEL004855-RA ADP, ATP carrier protein & 0 & - & AGAP006782 & - & $\begin{array}{l}\text { Mitochondrial carrier } \\
\text { protein }\end{array}$ \\
\hline 12 & 4 & AAEL000010-RB ribosomal protein L36, putative & 0 & - & AGAP002921 & CG7622 & \\
\hline 13 & 7 & AAEL002832-RA 40S ribosomal protein S26 & 0 & - & AGAP012100 & CG10305 & \\
\hline 14 & 2 & AAEL010668-RA quinone oxidoreductase & $6 e-92$ & Supercont 1.363 & AGAP006478 & - & Alcohol dehydrogenase \\
\hline 15 & 2 & AAEL004851-RA hypothetical protein & $2 \mathrm{e}-33$ & - & - & - & \\
\hline 16 & & AAEL011400-RA conserved hypothetical protein & 0 & - & - & - & Fibrinogen \\
\hline 17 & 2 & AAEL014562-RA 60S ribosomal protein L12 & 0 & - & AGAP010065 & CG3195 & \\
\hline 18 & 2 & No hits found & e-138 & Supercont1.495 & - & - & \\
\hline 19 & 6 & AAEL015404-RA lysozyme P, putative & 0 & - & AGAP007347 & CG1165 & \\
\hline 20 & 3 & AAEL002737-RA cytochrome c oxidase, subunit VIIC, putative & e-113 & - & AGAP007621 & CG2249 & \\
\hline 23 & 1 & AAEL009423-RA cd36 antigen & 0 & Supercont 1.408 & AGAP010133 & CG31741 & Adhesion molecule \\
\hline 24 & 2 & AAEL003559-RA conserved hypothetical protein & e-168 & Supercont1.114 & AGAP005874 & CG2669 & \\
\hline 26 & 1 & AAEL004420-RB conserved hypothetical protein & 0.003 & Supercont 1.574 & AGAP005036 & CG3857 & \\
\hline 27 & 1 & AAEL014052-RC endoplasmic reticulum protein erp29 & $3 e-50$ & Supercont 1.377 & AGAP000395 & CG7225 & \\
\hline 28 & 1 & AAEL002094-RA conserved hypothetical protein & 0 & Supercont 1.550 & - & CG18265 & Zinc finger \\
\hline 30 & 1 & AAEL014039-RB conserved hypothetical protein & e-129 & - & AGAP000669 & CG30415 & \\
\hline 31 & 2 & AAEL002534-RA 60S ribosomal protein L10 & e-77 & - & AGAP000953 & CG17521 & \\
\hline 33 & 1 & AAEL007868-RA ubiquinol-cytochrome c reductase complex $14 \mathrm{kd}$ pro & e-175 & - & AGAP012188 & CG17856 & \\
\hline 34 & 3 & AAEL008188-RA 60S ribosomal protein L6 & $2 \mathrm{e}-32$ & - & AGAP001911 & CG11522 & \\
\hline 35 & 2 & AAEL009724-RA hypothetical protein & 0.00007 & & & & Zinc finger \\
\hline 36 & 1 & AAEL013272-RA 60S ribosomal protein L37a & $9 e-95$ & - & AGAP009920 & CG5827 & \\
\hline 38 & 1 & AAEL004523-RA SecY protein & 0 & Supercont 1.122 & & & \\
\hline 39 & 1 & AAEL003349-RA NADPH cytochrome P450 reductase & e-116 & - & AGAP000500 & CG11567 & \\
\hline 40 & 2 & AAEL003347-conserved hypothetical protein & 0 & Supercont 1.84 & - & - & $\begin{array}{l}\text { Cellular retinaldehyde- } \\
\text { binding/triple function }\end{array}$ \\
\hline 41 & 2 & No hits found & 0 & Supercont1.968 & AGAP000952 & CG9091 & Ribosomal protein $60 \mathrm{~S}$ \\
\hline
\end{tabular}




\begin{tabular}{|c|c|c|c|c|c|c|c|}
\hline Contig & $\mathrm{n}$ & vs. Ae. aegypti Liverpool strain transcripts & e & $\begin{array}{l}\text { vs. Liverpool strain } \\
\text { genomic supercontigs }\end{array}$ & $\begin{array}{l}\text { vs. Anopheles } \\
\text { gambiae }\end{array}$ & $\begin{array}{l}\text { vs. Drosophila } \\
\text { melanogaster }\end{array}$ & Function \\
\hline 42 & 1 & AAEL007011-RA conserved hypothetical protein & $7 e-65$ & - & AGAP004256 & CG11259 & LIM, zinc-binding \\
\hline 43 & 2 & AAEL002325-RA conserved hypothetical protein & $2 \mathrm{e}-34$ & Supercont 1.285 & AGAP007143 & CG32210 & \\
\hline 44 & 1 & AAEL003791-RA conserved hypothetical protein & e-139 & Supercont 1.77 & AGAP000261 & CG7556 & $\begin{array}{c}\text { Myb, DNA-binding Heat } \\
\text { shock protein DnaJ, N- } \\
\text { terminal }\end{array}$ \\
\hline 45 & 1 & AAEL002115-RA hypothetical protein & $3 e-64$ & Supercont 1.86 & - & - & Zinc finger, C2H2-type \\
\hline 43 & 2 & AAEL014048-RA hypothetical protein & $2 \mathrm{e}-34$ & Supercont 1.285 & AGAP009925 & CG11614 & Recoverin \\
\hline 44 & 1 & AAEL003791-RA conserved hypothetical protein & $\mathrm{e}-139$ & Supercont 1.77 & AGAP000261 & CG7556 & $\begin{array}{c}\text { Myb, DNA-binding Heat } \\
\text { shock protein DnaJ, N- } \\
\text { terminal }\end{array}$ \\
\hline 45 & 1 & AAEL002115-RA hypothetical protein & $3 e-64$ & Supercont 1.86 & - & - & Zinc finger, $\mathrm{C} 2 \mathrm{H} 2$-type \\
\hline 47 & 1 & AAEL009770-RA ubiquitin-conjugating enzyme, E2 & $\mathrm{e}-114$ & Supercont 1.428 & AGAP000495 & CG3018 & $\begin{array}{l}\text { Ubiquitin (protein process- } \\
\text { ing) }\end{array}$ \\
\hline 49 & 2 & AAEL009506-RA 40S ribosomal protein S20 & $2 \mathrm{e}-59$ & Supercont 1.725 & AGAP010591 & CG15693 & \\
\hline 50 & 1 & AAEL012039-RA zinc finger protein & $4 \mathrm{e}-63$ & Supercont1.644 & AGAP004637 & CG2125 & \\
\hline 51 & 2 & AAEL013407-RA catalase & $6 e-21$ & - & AGAP004904 & CG6871 & \\
\hline 52 & 1 & AAEL008629-RA abc transporter & 0 & - & - & CG9663 & ATPase \\
\hline 55 & 3 & AAEL002339-RA conserved hypothetical protein & $4 e-25$ & Supercont 1.410 & AGAP004671 & CG4738 & \\
\hline 56 & 1 & AAEL013271-RA organic cation transporter & $2 \mathrm{e}-46$ & Supercont 1.47 & AGAP008335 & CG9317 & $\begin{array}{l}\text { Major facilitator super- } \\
\text { family general substrate } \\
\text { transporter }\end{array}$ \\
\hline 57 & 3 & AAEL012750-RA transcription factor TFIIH-subunit, putative & 0 & Supercont 1.495 & AGAP011110 & CG8151 & \\
\hline 58 & 1 & AAEL000352-RA hypothetical protein & $8 \mathrm{e}-15$ & - & - & - & \\
\hline 59 & 1 & AAEL003945-RA transcription initiation factor IIF alpha subunit & $6 e-59$ & - & AGAP002779 & CG10281 & \\
\hline 63 & 2 & AAEL007824-RA ribosomal protein S29, putative & $2 \mathrm{e}-46$ & Supercont 1.47 & AGAP001595 & CG8495 & \\
\hline 64 & 1 & AAEL010243-RA abnormal X segregation, putative & 0 & Supercont1.1113 & AGAP009776 & CG9703 & Nuclear metabolism \\
\hline 65 & 1 & AAEL013865-RA conserved hypothetical protein & $\mathrm{e}-157$ & - & - & CG30380 & \\
\hline 66 & 1 & AAEL003799-RA conserved hypothetical protein & 0 & Supercont1.97 & - & - & \\
\hline 67 & 1 & No hits found & $\mathrm{e}-130$ & Supercont 1.382 & - & - & \\
\hline 68 & 11 & AAEL013583-RA 60S ribosomal protein L23 & $4 \mathrm{e}-21$ & - & AGAP010252 & CG3661 & \\
\hline 70 & 1 & AAEL000582-RA pickpocket & $\mathrm{e}-159$ & Supercont 1.590 & - & CG9703 & $\begin{array}{l}\mathrm{Na}+\text { channel, amiloride- } \\
\text { sensitive }\end{array}$ \\
\hline 73 & 2 & AAEL006169-RA cathepsin d & 0 & - & AGAP003277 & CG10104 & \\
\hline 74 & 1 & AAEL004744-RA ccaat-binding transcription factor subunit a & 0 & - & AGAP008344 & CG10447 & \\
\hline 75 & 1 & AAEL011711-RA nascent polypeptide associated complex alpha subun & $\mathrm{e}-132$ & - & AGAP006766 & CG8759 & \\
\hline 76 & 1 & AAEL007633-RA dihydropyrimidinase & 0 & - & AGAP003124 & CG1411 & Nuclear metabolism \\
\hline
\end{tabular}




\begin{tabular}{|c|c|c|c|c|c|c|c|}
\hline Contig & $\mathrm{n}$ & vs. Ae. aegypti Liverpool strain transcripts & e & $\begin{array}{l}\text { vs. Liverpool strain } \\
\text { genomic supercontigs }\end{array}$ & $\begin{array}{l}\text { vs. Anopheles } \\
\text { gambiae }\end{array}$ & $\begin{array}{l}\text { vs. Drosophila } \\
\text { melanogaster }\end{array}$ & Function \\
\hline 77 & 1 & AAEL007431-RA conserved hypothetical protein & e-105 & - & AGAP005149 & CG7637 & $\begin{array}{l}\text { Nucleolar RNA-binding } \\
\text { protein Nop10p }\end{array}$ \\
\hline 78 & & AAEL006448-RA hypothetical protein & $5 e-66$ & Supercont 1.537 & AGAP010934 & - & TonB box, N-terminal \\
\hline 79 & 1 & AAEL013173-RA calcium/calmodulin-dependent protein kinase type 1 & 0 & Supercont1.65 & AGAP009034 & CG17528 & Doublecortin \\
\hline 80 & 1 & AAEL008854-RA conserved hypothetical protein & 0 & - & AGAP007954 & CG12099 & Zinc finger \\
\hline 83 & 1 & AAEL004510-RA hypothetical protein & $3 e-81$ & - & - & - & \\
\hline 84 & 1 & AAEL004791-RA sorting nexin & $2 \mathrm{e}-94$ & Supercont1.19 & AGAP002081 & - & $\begin{array}{l}\text { Regulator of } G \text { protein } \\
\text { signalling }\end{array}$ \\
\hline 85 & 1 & AAEL001275-RA ef-hand protein nucb1 Flagellar calcium-bindinprotein & 0 & - & AGAP005608 & CG32190 & Calflagin \\
\hline 86 & 1 & AAEL009634-RD steroid dehydrogenase & e-106 & - & AGAP004532 & CG1444 & $\begin{array}{l}\text { Insect alcohol dehydroge- } \\
\text { nase family }\end{array}$ \\
\hline 88 & 1 & AAEL003594-RA kinectin, putative & 0 & Supercont 1.173 & - & - & \\
\hline 89 & 1 & AAEL001930-RA pra1 protein & $\mathrm{e}-122$ & - & AGAP005121 & CG10373 & $\begin{array}{l}\text { Prenylated rab acceptor } \\
\text { PRA1 }\end{array}$ \\
\hline 90 & 1 & AAEL003105-RA supervillin & $4 \mathrm{e}-76$ & Supercont 1.442 & AGAP007181 & CG33232 & Gelsolin \\
\hline 91 & 2 & No hits found & 0 & Supercont 1.324 & - & - & \\
\hline 92 & 1 & AAEL011662-RA plasma glutamate carboxypeptidase & $\mathrm{e}-134$ & Supercont 1.106 & AGAP001262 & - & Protease-associated PA \\
\hline 93 & 1 & AAEL008864-RA conserved hypothetical protein & $6 e-56$ & Supercont1.85 & AGAP010432 & CG8531 & Heat shock protein DnaJ \\
\hline 94 & 1 & AAEL004829-RA NADH dehydrogenase, putative & 0 & - & AGAP005621 & CG6463 & ETC complex I subunit \\
\hline 95 & 1 & AAEL007385-RB ferritin subunit 1 & e-113 & - & AGAP002465 & CG2216 & \\
\hline 96 & 1 & AAEL012585-RA 60S ribosomal protein L7 & e-150 & - & AGAP008916 & CG4897 & \\
\hline 97 & 1 & AAEL002190-RA conserved hypothetical protein & $1 e-45$ & - & AGAP008492 & CG4619 & \\
\hline 98 & 2 & AAEL010943-RA conserved hypothetical protein & $\mathrm{e}-170$ & - & AGAP003734 & - & $\begin{array}{l}\text { Cellular retinaldehyde- } \\
\text { binding/triple function }\end{array}$ \\
\hline 99 & 1 & AAEL002013-RA hypothetical protein & $6 e-15$ & - & - & - & Zinc finger \\
\hline 100 & 1 & AAEL011471-RC 60S ribosomal protein L17 & 0 & - & AGAP001459 & CG3203 & \\
\hline 101 & 1 & AAEL013273-RA hypothetical protein & 0 & - & - & - & \\
\hline 102 & 1 & AAEL012241-RA hypothetical protein & e-118 & Supercont1.109 & AGAP005919 & - & \\
\hline 103 & 1 & AAEL000795-RA ubiquitin & $4 \mathrm{e}-94$ & - & - & - & \\
\hline 104 & 1 & AAEL009737-RA conserved hypothetical protein & e-129 & - & AGAP005448 & CG9227 & \\
\hline 105 & 1 & AAEL014815-RA vacuolar protein sorting-associated protein (vps13) & 0 & Supercont 1.593 & AGAP003489 & CG15523 & $\begin{array}{l}\text { Immunoglobulin/major his- } \\
\text { tocompatibility complex }\end{array}$ \\
\hline 106 & 1 & AAEL000572-RA amp dependent ligase & e-109 & Supercont 1.11 & AGAP001763 & CG30194 & $\begin{array}{l}\text { AMP-dependent synthetase } \\
\text { and ligase }\end{array}$ \\
\hline 110 & & AAEL011870-RA rap55 & $1 \mathrm{e}-142$ & - & AGAP006935 & CG10686 & Proline-rich region \\
\hline 111 & 2 & AAEL008883-RA conserved hypothetical protein & 0 & - & AGAP006471 & CG18809 & \\
\hline 112 & 1 & AAEL014018-RA conserved hypothetical protein & e-129 & Supercont1.83 & AGAP006045 & CG4005 & WW/Rsp5/WWP \\
\hline 113 & 2 & No hits found & $\mathrm{e}-179$ & Supercont1.89 & - & - & \\
\hline
\end{tabular}




\begin{tabular}{|c|c|c|c|c|c|c|c|}
\hline Contig & $\mathrm{n}$ & vs. Ae. aegypti Liverpool strain transcripts & e & $\begin{array}{l}\text { vs. Liverpool strain } \\
\text { genomic supercontigs }\end{array}$ & $\begin{array}{l}\text { vs. Anopheles } \\
\text { gambiae }\end{array}$ & $\begin{array}{l}\text { vs. Drosophila } \\
\text { melanogaster }\end{array}$ & Function \\
\hline 114 & 2 & AAEL012698-RA ATP-binding cassette sub-family A member 3, putative & $4 \mathrm{e}-54$ & Supercont 1.2584 & AGAP006379 & CG1718 & ATPase \\
\hline 115 & 2 & AAEL009341-RA ribosomal protein L34, putative & 0 & - & AGAP009324 & CG6090 & \\
\hline 116 & 2 & AAEL013536-RA ubiquitin & 0 & - & - & CG5271 & Ribosomal protein L40 \\
\hline 117 & 5 & AAEL013542-RA elongase, putative & 0 & - & AGAP003196 & CG16904 & $\begin{array}{l}\text { GNS1/SUR4 membrane } \\
\text { protein }\end{array}$ \\
\hline 119 & 1 & AAEL001977-RA conserved hypothetical protein & $1 e-57$ & Supercont 1.306 & AGAP008047 & CG3173 & $\begin{array}{l}\text { Phosphotransferase system, } \\
\text { HPr serine phosphorylation } \\
\text { site }\end{array}$ \\
\hline 120 & 1 & AAEL009038-RA prolylcarboxypeptidase, putative & 0 & - & AGAP005914 & CG9953 & Esterase/lipase/thioesterase \\
\hline 121 & 1 & AAEL012686-RA ribosomal protein S12, putative & $8 \mathrm{e}-51$ & Supercont 1.725 & - & CG8415 & \\
\hline 122 & 2 & AAEL004151-RC conserved hypothetical protein & e-120 & - & AGAP006612 & CG10071 & Ribosomal L29e protein \\
\hline 123 & 1 & AAEL010053-RA conserved hypothetical protein & $2 \mathrm{e}-47$ & Supercont 1.42 & AGAP002065 & CG13848 & $\begin{array}{c}\text { Cellular retinaldehyde } \\
\text { binding/alpha-tocopherol } \\
\text { transport }\end{array}$ \\
\hline 124 & 1 & AAEL010368-RB conserved hypothetical protein & $9 e-20$ & Supercont 1.148 & AGAP006232 & CG4289 & $\begin{array}{l}\text { Peroxisomal membrane } \\
\text { anchor protein }\end{array}$ \\
\hline 125 & 1 & AAEL007898-RA calmin & $2 \mathrm{e}-24$ & Supercont 1.772 & AGAP009554 & CG33715 & Spectrin repeat \\
\hline 126 & 1 & AAEL006406-RC conserved hypothetical protein & 0.013 & Supercont 1.204 & - & - & $\begin{array}{c}\text { Pheromone/general odorant } \\
\text { binding protein }\end{array}$ \\
\hline 127 & 1 & AAEL008770-RA proteasome subunit beta type & e-119 & - & AGAP004991 & - & \\
\hline 128 & 1 & No hits found & e-121 & Supercont1.136 & - & - & \\
\hline 129 & 1 & AAEL010819-RB vacuolar ATP synthase subunit H & $\mathrm{e}-155$ & - & AGAP003588 & CG11589 & Cell signalling \\
\hline 130 & 1 & AAEL012733-RA 60S ribosomal protein L19 & $1 \mathrm{e}-59$ & - & AGAP004422 & CG2746 & \\
\hline 131 & & No hits found & 0.71 & Supercont 1.36 & - & - & \\
\hline 132 & 1 & AAEL006860-RA ribosomal protein S28, putative & $2 \mathrm{e}-36$ & - & AGAP003412 & CG15527 & \\
\hline 133 & 2 & AAEL009214-RA diazepam binding inhibitor, putative & e-120 & - & AGAP007460 & CG8627 & Acyl-coA-binding protein \\
\hline 134 & 1 & AAEL002160-RA gtp-binding protein & 0 & - & AGAP000672 & CG1354 & Cell signalling \\
\hline 135 & 2 & AAEL002527-RA conserved hypothetical protein & $1 \mathrm{e}-62$ & - & AGAP000022 & CG2791 & $\begin{array}{c}\text { Alpha amylase, catalytic } \\
\text { subdomain }\end{array}$ \\
\hline 137 & 1 & AAEL001134-RA methylmalonate-semialdehyde dehydrogenase & e-124 & - & AGAP002499 & CG17896 & \\
\hline 138 & 1 & AAEL015108-RA conserved hypothetical protein & 0.020 & - & AGAP006965 & CG8793 & $\begin{array}{l}\text { ATPase, F1/V1/A1 com- } \\
\text { plex, alpha/beta subunit, } \\
\text { nucleotide-binding }\end{array}$ \\
\hline 139 & 1 & AAEL010308-RA hypothetical protein & $\mathrm{e}-112$ & Supercont 1.247 & AGAP011070 & CG18490 & \\
\hline 142 & 1 & AAEL007923-RA eukaryotic translation initiation factor 4 gamma & 0 & - & AGAP004750 & CG3845 & \\
\hline 143 & 1 & AAEL008136-RA conserved hypothetical protein & 0 & - & AGAP003975 & CG14716 & Haem oxygenase \\
\hline 144 & 1 & AAEL004068-RA hypothetical protein & 0.004 & - & - & - & $\begin{array}{l}\text { HMG-I and HMG-Y, DNA- } \\
\text { binding }\end{array}$ \\
\hline
\end{tabular}




\begin{tabular}{|c|c|c|c|c|c|c|c|}
\hline Contig & $\mathrm{n}$ & vs. Ae. aegypti Liverpool strain transcripts & e & $\begin{array}{l}\text { vs. Liverpool strain } \\
\text { genomic supercontigs }\end{array}$ & $\begin{array}{l}\text { vs. Anopheles } \\
\text { gambiae }\end{array}$ & $\begin{array}{l}\text { vs. Drosophila } \\
\text { melanogaster }\end{array}$ & Function \\
\hline 145 & 10 & AAEL010668-RA quinone oxidoreductase & e-106 & Supercont 1.363 & AGAP006478 & - & $\begin{array}{c}\text { Alcohol dehydrogenase } \\
\text { GroES-like }\end{array}$ \\
\hline 146 & 3 & AAEL007023-RA estradiol 17 beta-dehydrogenase & 0 & - & AGAP008667 & CG3415 & Fatty acid synthase \\
\hline 147 & 1 & AAEL009626-RA ankyrin repeat domain protein & $8 \mathrm{e}-10$ & - & - & - & $\begin{array}{l}\text { Immunoglobulin/ } \\
\text { major histocompatibility } \\
\text { complex }\end{array}$ \\
\hline 148 & 3 & AAEL009994-RA 60S ribosomal protein L4 & e-131 & - & AGAP002306 & CG5502 & \\
\hline 149 & 2 & AAEL003893-RA dna repair protein xp-c/rad4 & 0 & Supercont 1.470 & AGAP003342 & CG8153 & \\
\hline 150 & 1 & AAEL013434-RA Spatzle 1A & $5 e-04$ & Supercont1.53 & - & - & \\
\hline 152 & 2 & AAEL000987-RA 60S ribosomal protein L8 & 0 & - & AGAP005802 & CG1263 & \\
\hline 153 & 1 & AAEL000765-RA hexamerin 2 beta & 0 & - & - & CG2559 & $\begin{array}{l}\text { Arthropod hemocyanin/ } \\
\text { insect LSP }\end{array}$ \\
\hline 154 & 1 & AAEL001764-RA histone-fold protein CHRAC subunit, putative & e-130 & - & AGAP005051 & CG13399 & $\begin{array}{l}\text { Histone-like transcription } \\
\text { factor/archaeal histone/ } \\
\text { DNA topoisomerase }\end{array}$ \\
\hline 155 & 1 & No hits found & 0 & Supercont 1.658 & - & - & \\
\hline 156 & 1 & AAEL010017-RA cytochrome B5 & e-177 & - & AGAP007121 & CG2140 & \\
\hline 158 & 1 & AAEL007833-RA hypothetical protein & e-124 & - & - & - & \\
\hline 159 & 1 & AAEL006472-RA rabconnectin & e-116 & Supercont 1.388 & AGAP010490 & CG3585 & WD-40 repeat \\
\hline 160 & 1 & AAEL001247-RA conserved hypothetical protein & e-121 & - & AGAP005602 & CG15715 & Zinc finger \\
\hline 161 & & No hits found & e-171 & Supercont 1.296 & - & - & \\
\hline 162 & 1 & AAEL003063-RA semaphorin & $5 e-69$ & Supercont 1.284 & AGAP005742 & CG6446 & \\
\hline 163 & 2 & AAEL005753-RA serine protease & $3 e-80$ & - & - & - & \\
\hline 164 & 1 & AAEL015617-RA conserved hypothetical protein & e-106 & - & AGAP007614 & CG30173 & \\
\hline 165 & 1 & AAEL009925-RA amidase & $5 e-87$ & - & AGAP002377 & CG7900 & \\
\hline 166 & 1 & AAEL012122-RA 26S proteasome regulatory subunit S3 & 2e-99 & Supercont 1.125 & AGAP009082 & CG10484 & \\
\hline 167 & 1 & AAEL011010-RA conserved hypothetical protein & $6 e-97$ & - & AGAP012515 & CG4692 & \\
\hline 168 & 1 & AAEL002568-RA conserved hypothetical protein & $3 e-87$ & - & - & - & EGF-like region \\
\hline 169 & 1 & AAEL013236-RA proteasome subunit beta type 5,8 & e-173 & - & AGAP010718 & CG12323 & \\
\hline 170 & 1 & AAEL009699-RA hypothetical protein & $4 e-34$ & Supercont 1.998 & - & - & Cytochrome P450 \\
\hline 171 & 1 & AAEL015592-RA structural maintenance of chromosomes smc1 & 0 & Supercont 1.612 & AGAP002947 & CG6057 & $\mathrm{ABC}$ transporter related \\
\hline 172 & 1 & AAEL009782-RA brain chitinase and chia & $2 \mathrm{e}-45$ & - & AGAP000436 & CG3044 & \\
\hline 173 & 1 & AAEL013221-RC 60S ribosomal protein L10a & 0 & - & AGAP011298 & CG3843 & \\
\hline 174 & 1 & AAEL006482-RA sugar transporter & $4 e-60$ & Supercont1.127 & AGAP001160 & CG31100 & \\
\hline 175 & 1 & AAEL007679-RA conserved hypothetical protein & 0 & - & - & CG13994 & $\begin{array}{l}\text { Protein phosphatase } \\
\text { inhibitor }\end{array}$ \\
\hline 176 & 1 & AAEL008731-RA hypothetical protein & $2 \mathrm{e}-89$ & - & - & - & \\
\hline
\end{tabular}




\begin{tabular}{|c|c|c|c|c|c|c|c|}
\hline Contig & $\mathrm{n}$ & vs. Ae. aegypti Liverpool strain transcripts & $\mathrm{e}$ & $\begin{array}{l}\text { vs. Liverpool strain } \\
\text { genomic supercontigs }\end{array}$ & $\begin{array}{l}\text { vs. Anopheles } \\
\text { gambiae }\end{array}$ & $\begin{array}{l}\text { vs. Drosophila } \\
\text { melanogaster }\end{array}$ & Function \\
\hline 177 & 1 & AAEL006203-RA Juvenile hormone-inducible protein, putative & 0 & Supercont1.162 & - & - & \\
\hline 178 & 1 & AAEL013007-RA cytochrome c oxidase, subunit VB, putative & 0 & - & AGAP008724 & CG11015 & \\
\hline 180 & 1 & AAEL006698-RA 60S ribosomal protein L31 & e-107 & - & AGAP011896 & CG1821 & \\
\hline 181 & 1 & AAEL009608-RA 28S ribosomal protein S16, mitochondrial & 0 & - & AGAP004818 & CG8338 & \\
\hline 182 & 1 & AAEL003020-RA tailless & 0 & Supercont 1.195 & AGAP000819 & CG1378 & $\begin{array}{c}\text { Nuclear hormone receptor, } \\
\text { DNA-bindin }\end{array}$ \\
\hline 184 & & AAEL001887 & e-116 & Supercont 1.45 & AGAP008988 & CG2718 & $\begin{array}{l}\text { Glutamine synthetase } 1 \text {, } \\
\text { mitochondrial precursor }\end{array}$ \\
\hline 185 & 4 & AAEL008219-RA elongase, putative & $7 e-07$ & - & AGAP007264 & - & \\
\hline 186 & 1 & AAEL000640-RB alanine-glyoxylate aminotransferase & $3 e-10$ & - & AGAP012404 & CG11241 & Aminotransferase class-III \\
\hline 187 & 2 & AAEL003324-RA acidic ribosomal protein P1, putative & $6 e-10$ & - & AGAP007740 & CG4087 & Ribosomal protein $60 \mathrm{~S}$ \\
\hline 189 & 2 & AAEL008481-RB 60S ribosomal protein L18 & $8 \mathrm{e}-67$ & - & AGAP007580 & CG8615 & \\
\hline 191 & 1 & AAEL004071-RA nitrogen fixation protein nifu & 0 & & AGAP005813 & CG9836 & \\
\hline 193 & 1 & AAEL004027-RA glucose dehydrogenase & 0 & - & - & CG9509 & Alcohol oxidase \\
\hline 194 & 1 & AAEL004175-RA 40S ribosomal protein S17 & 0 & - & AGAP004887 & CG3922 & \\
\hline 195 & 1 & AAEL001164-RA NADH:ubiquinone dehydrogenase, putative & 0 & - & AGAP008653 & CG3214 & Proton-pumping \\
\hline 198 & 1 & AAEL003505-RA jun & 0 & Supercont 1.1051 & AGAP006386 & CG2275 & Transcription factor Jun \\
\hline 199 & 1 & AAEL004120-RA Niemann-Pick Type C-2, putative & 0 & - & AGAP012352 & CG11314 & $\begin{array}{c}\text { protein and Def2/Der2 } \\
\text { allergen-immunoglobulin- } \\
\text { like }\end{array}$ \\
\hline 200 & 1 & AAEL011056-RA transcription factor HES-1 & $1 e-53$ & Supercont 1.809 & - & CG10446 & $\begin{array}{l}\text { Basic helix-loop-helix dim- } \\
\text { erisation region bHLH }\end{array}$ \\
\hline 201 & 1 & AAEL005901-RB 40S ribosomal protein S3a & e-136 & - & AGAP003532 & CG2168 & \\
\hline 202 & 1 & AAEL011287-RA ubiquitin specific protease & 0 & Supercont 1.793 & AGAP000884 & CG15817 & $\begin{array}{l}\text { Involucrin repeat-insoluble } \\
\text { envelope beneath the } \\
\text { plasma membrane }\end{array}$ \\
\hline 203 & 1 & AAEL013661-RA actin binding protein, putative (thymosin beta-4-) & $8 \mathrm{e}-81$ & Supercont 1.304 & AGAP000235 & CG4944 & \\
\hline 204 & 1 & AAEL005725-RA conserved hypothetical protein & $3 e-51$ & Supercont 1.470 & AGAP002839 & CG3184 & $\begin{array}{l}\text { WD-40 repeat signal } \\
\text { transduction and transcrip- } \\
\text { tion regulation to cell cycle } \\
\text { control and apoptosis }\end{array}$ \\
\hline 205 & 1 & AAEL007283-RA acetyl-coa synthetase & $3 e-85$ & - & AGAP001473 & CG6432 & $\begin{array}{c}\text { Long chain fatty acid Co-A } \\
\text { ligase }\end{array}$ \\
\hline 206 & 1 & AAEL001501-RA anamorsin, putative & 0.44 & - & AGAP008883 & CG4180 & \\
\hline 207 & 1 & AAEL009124-RA cytochrome P450 & 0 & Supercont 1.390 & - & CG10240 & \\
\hline 208 & 1 & AAEL002533-RA conserved hypothetical protein & $\mathrm{e}-144$ & - & AGAP001084 & CG4020 & $\begin{array}{c}\text { Male sterility protein-that } \\
\text { converts wax fatty acids to } \\
\text { fatty alcohols }\end{array}$ \\
\hline
\end{tabular}




\begin{tabular}{|c|c|c|c|c|c|c|c|}
\hline Contig & $\mathrm{n}$ & vs. Ae. aegypti Liverpool strain transcripts & $\mathrm{e}$ & $\begin{array}{l}\text { vs. Liverpool strain } \\
\text { genomic supercontigs }\end{array}$ & $\begin{array}{l}\text { vs. Anopheles } \\
\text { gambiae }\end{array}$ & $\begin{array}{l}\text { vs. Drosophila } \\
\text { melanogaster }\end{array}$ & Function \\
\hline 209 & 1 & AAEL004691-RA ring finger & 0 & - & AGAP005202 & CG16982 & $\begin{array}{l}\text { Zinc finger bind DNA, } \\
\text { RNA, protein and/or lipid } \\
\text { substrates }\end{array}$ \\
\hline 210 & 2 & AAEL010756-RA 40S ribosomal protein S19 & $1 \mathrm{e}-71$ & - & AGAP010933 & CG4464 & \\
\hline 211 & 1 & AAEL014903-RA 40S ribosomal protein S24 & $2 \mathrm{e}-44$ & - & AGAP005131 & CG3751 & \\
\hline 212 & & No hits found & $2 \mathrm{e}-49$ & Supercont 1.222 & - & - & \\
\hline 214 & 2 & AAEL008144-RA amp dependent ligase & 0 & - & AGAP010870 & CG3394 & $\begin{array}{l}\text { AMP synthaselong chain } \\
\text { fatty acid Co-A ligase, } \\
\text { acetyl-CoA synthetase }\end{array}$ \\
\hline 215 & 2 & AAEL009257-RA conserved hypothetical protein & e-130 & - & AGAP007768 & CG14028 & $\begin{array}{l}\text { Cytochrome c oxidase } \\
\text { subunit VIc }\end{array}$ \\
\hline 216 & 1 & AAEL006096-RA Gelsolin precursor & 0 & - & AGAP011369 & CG1106 & \\
\hline 217 & 1 & AAEL011295-RA conserved hypothetical protein & e-120 & & AGAP008921 & & \\
\hline 218 & 1 & AAEL011042-RA conserved hypothetical protein & 0 & - & AGAP006832 & - & \\
\hline 220 & 1 & AAEL003921-RA anopheles stephensi ubiquitin, putative & e-133 & - & AGAP002389 & CG7215 & \\
\hline 221 & 1 & AAEL010731-RA conserved hypothetical protein & e-168 & - & AGAP009095 & CG3077 & $\begin{array}{l}\text { Phox-like-cell signalling, } \\
\text { vesicular trafficking, protein } \\
\text { sorting and lipid modifica- } \\
\text { tion }\end{array}$ \\
\hline 222 & 1 & AAEL002565-RA titin & $1 \mathrm{e}-92$ & Supercont1.113 & AGAP001633 & CG32019 & $\begin{array}{l}\text { Immunoglobulin-like } \\
\text { domains }\end{array}$ \\
\hline 224 & 1 & AAEL003320-RA conserved hypothetical protein & $3 e-38$ & Supercont 1.1024 & AGAP004724 & - & $\begin{array}{c}\text { Salmonella/Shigella invasin } \\
\text { protein C }\end{array}$ \\
\hline 225 & 2 & AAEL002401-RA proteasome subunit beta type & e-176 & - & AGAP008837 & CG17301 & \\
\hline 226 & 2 & AAEL013574-RB apolipoprotein D, putative & e-168 & - & AGAP011478 & - & Transport of nutrients \\
\hline 227 & 1 & AAEL005931-RA 6-phosphogluconate dehydrogenase & e-140 & - & AGAP004197 & CG3724 & \\
\hline 228 & 1 & AAEL004180-RA conserved hypothetical protein & $3 e-70$ & Supercont 1.311 & AGAP000106 & CG7277 & $\begin{array}{c}\text { Aerobic ubiquinone biosyn- } \\
\text { thesis pathway }\end{array}$ \\
\hline 229 & 1 & AAEL010405-RA alkyldihydroxyacetonephosphate synthase & $6 e-74$ & - & AGAP004358 & CG10253 & $\begin{array}{l}\text { Catalyses the oxidation of a } \\
\text { wide variety of substrates }\end{array}$ \\
\hline 230 & 1 & AAEL010573-RB ribosomal protein S25, putative & $8 \mathrm{e}-89$ & - & AGAP004462 & CG6684 & \\
\hline 231 & 1 & AAEL012798-RA lumbrokinase-3(1) precursor, putative & $2 \mathrm{e}-24$ & Supercont 1.566 & - & - & $\begin{array}{l}\text { Peptidase S1A, chymot- } \\
\text { rypsin }\end{array}$ \\
\hline 232 & 1 & AAEL014555-RA Ump1p protein, putative & 0 & - & AGAP009647 & CG9324 & $\begin{array}{c}\text { Proteasome maturation fac- } \\
\text { tor UMP1 }\end{array}$ \\
\hline 233 & 1 & AAEL013614-RB clathrin heavy chain & 0 & Supercont 1.48 & AGAP009647 & CG9324 & \\
\hline 235 & 1 & AAEL002017-RA protein serine/threonine kinase, putative & $4 e-98$ & Supercont1.83 & - & CG11390 & $\begin{array}{l}\text { Insect pheromone-binding } \\
\text { protein A10/OS-D }\end{array}$ \\
\hline 236 & 1 & AAEL002293-RA conserved hypothetical protein & e-113 & - & AGAP011825 & - & \\
\hline
\end{tabular}




\begin{tabular}{|c|c|c|c|c|c|c|c|}
\hline Contig & $\mathrm{n}$ & vs. Ae. aegypti Liverpool strain transcripts & $\mathrm{e}$ & $\begin{array}{l}\text { vs. Liverpool strain } \\
\text { genomic supercontigs }\end{array}$ & $\begin{array}{l}\text { vs. Anopheles } \\
\text { gambiae }\end{array}$ & $\begin{array}{l}\text { vs. Drosophila } \\
\text { melanogaster }\end{array}$ & Function \\
\hline 237 & 2 & AAEL006389-RA cathepsin 1 & $9 \mathrm{e}-63$ & - & AGAP012577 & CG8947 & \\
\hline 238 & 1 & AAEL003471-RA hypothetical protein & $1 \mathrm{e}-48$ & Supercont 1.744 & AGAP004764 & - & Zinc finger \\
\hline 239 & 1 & AAEL005997-RA allergen, putative & 0 & - & - & CG6783 & Cytosolic fatty-acid binding \\
\hline 240 & 12 & AAEL006824-RA cytochrome P450 & 0 & - & AGAP000877 & - & \\
\hline 241 & 1 & AAEL012224-RA zinc finger protein & $4 e-39$ & - & AGAP009068 & - & \\
\hline 242 & 1 & AAEL006050-RA nuclear RNA export factor 2 (NXF2), putative & $4 \mathrm{e}-37$ & Supercont 1.42 & AGAP002004 & CG4118 & $\begin{array}{l}\text { Regulates all receptor-me- } \\
\text { diated transport between the } \\
\text { nucleus and the cytoplasm }\end{array}$ \\
\hline 243 & 1 & AAEL007869-RA hypothetical protein & $2 \mathrm{e}-92$ & - & - & - & Zinc finger \\
\hline 244 & 1 & AAEL009080-RA importin 7 & $6 e-33$ & Supercont1.288 & AGAP007299 & CG7935 & \\
\hline 246 & 1 & AAEL008786-RA caax prenyl protease ste24 & $4 \mathrm{e}-37$ & Supercont 1.37 & AGAP004470 & CG9000 & $\begin{array}{l}\text { ABC transporter related- } \\
\text { which uses the hydrolysis } \\
\text { of ATP to energize diverse } \\
\text { biological systems }\end{array}$ \\
\hline 247 & 1 & AAEL011656-RA 40S ribosomal protein S15 & $1 \mathrm{e}-27$ & - & AGAP001274 & CG8332 & \\
\hline 248 & 1 & AAEL010230-RA NADH:ubiquinone dehydrogenase, putative & $1 \mathrm{e}-92$ & Supercont 1.113 & AGAP009865 & CG9306 & $\begin{array}{l}\text { Complex } 1 \text { LYR protein- } \\
\text { believed to be be required } \\
\text { for iron-sulphur custer } \\
\text { biogenesis }\end{array}$ \\
\hline 249 & 1 & AAEL008583-RA conserved hypothetical protein & $\mathrm{e}-150$ & Supercont1.96 & AGAP011880 & CG8833 & $\begin{array}{l}\text { DNA-damage-repair } \\
\text { proteins }\end{array}$ \\
\hline 250 & 1 & AAEL002933-RA conserved hypothetical protein & 0 & - & AGAP007147 & - & $\begin{array}{l}\text { Exosome-associated-DNA } \\
\text { double-strand repair }\end{array}$ \\
\hline 251 & 1 & AAEL007065-RA adp-ribosylation factor, arf & $\mathrm{e}-113$ & - & AGAP012014 & CG8385 & $\begin{array}{l}\text { Vesicle biogenesis in intra- } \\
\text { cellular traffic }\end{array}$ \\
\hline 252 & 1 & AAEL000171-RA hypothetical protein & $2 \mathrm{e}-78$ & Supercont 1.55 & - & - & Zinc finger \\
\hline 253 & 1 & AAEL001664-RA hypothetical protein & e-106 & - & - & - & \\
\hline 254 & 1 & AAEL003160-RA conserved hypothetical protein & $\mathrm{e}-105$ & - & - & CG6770 & \\
\hline 255 & 1 & AAEL011587-RA ribosomal protein L27, putative & 0 & - & AGAP011687 & CG4759 & \\
\hline 256 & & AAEL006061-RA proteasome subunit alpha type & $2 \mathrm{e}-73$ & - & AGAP001995 & CG5266 & \\
\hline 257 & 1 & AAEL011676-RA amp dependent coa ligase & 0 & Supercont 1.178 & AGAP008557 & CG12512 & $\begin{array}{l}\text { The family of enzymes } \\
\text { includes luciferase, long } \\
\text { chain fatty acid Co-A } \\
\text { ligase, acetyl-CoA syn- } \\
\text { thetase }\end{array}$ \\
\hline 258 & 1 & AAEL000912-RA conserved hypothetical protein & 0 & - & AGAP010788 & - & $\begin{array}{l}\text { Male sterility-involved in } \\
\text { male gametogenesis }\end{array}$ \\
\hline 259 & 2 & AAEL000673-RA conserved hypothetical protein & 0 & - & AGAP011983 & CG10424 & Carbohydrate kinase \\
\hline
\end{tabular}




\begin{tabular}{|c|c|c|c|c|c|c|c|}
\hline Contig & $\mathrm{n}$ & vs. Ae. aegypti Liverpool strain transcripts & e & $\begin{array}{l}\text { vs. Liverpool strain } \\
\text { genomic supercontigs }\end{array}$ & $\begin{array}{l}\text { vs. Anopheles } \\
\text { gambiae }\end{array}$ & $\begin{array}{l}\text { vs. Drosophila } \\
\text { melanogaster }\end{array}$ & Function \\
\hline 260 & 2 & AAEL013605-RA hypothetical protein & e-104 & - & AGAP006738 & CG34018 & $\begin{array}{c}\text { Proteinase inhibitor I1, } \\
\text { Kazal }\end{array}$ \\
\hline 261 & 1 & AAEL011314-RA epoxide hydrolase & 0 & - & AGAP008684 & CG15101 & Detoxification ofepoxides \\
\hline 262 & 1 & AAEL004341-RA alpha-esterase & 0 & - & AGAP006723 & CG9858 & \\
\hline 263 & 4 & AAEL005065-RA ptpla domain protein & 0 & - & AGAP003814 & CG6746 & $\begin{array}{l}\text { Protein tyrosine phos- } \\
\text { phatase-like protein, } \\
\text { PTPLA-post-translational }\end{array}$ \\
\hline 264 & 1 & AAEL008459-RA conserved hypothetical protein & 0.018 & - & AGAP000660 & CG4557 & \\
\hline 265 & 1 & AAEL005065-RA ptpla domain protein & 0 & - & AGAP003814 & CG6746 & Protein metabolism \\
\hline 266 & 1 & AAEL007771-RA 60S ribosomal protein L22 & $4 \mathrm{e}-$ & - & AGAP005046 & CG7434 & \\
\hline 267 & 1 & AAEL009810-RA sideroflexin 1,2,3 & $2 \mathrm{e}-94$ & Supercont 1.200 & AGAP007119 & CG6812 & $\begin{array}{l}\text { Tricarboxylate/iron carrier- } \\
\text { tricarboxylate carrier from } \\
\text { rat liver mitochondria }\end{array}$ \\
\hline 268 & 1 & AAEL011663-RA conserved hypothetical & e-149 & - & AGAP001271 & CG10228 & $\begin{array}{l}\text { Protein membrane target- } \\
\text { ing/cargo recognition role } \\
\text { in vesicular trafficking }\end{array}$ \\
\hline 269 & 1 & AAEL008131-RA cytidylate kinase & 0 & - & AGAP003968 & CG6092 & Adenylate kinase \\
\hline 270 & 1 & AAEL013676-RA 26S protease regulatory subunit & 0 & - & AGAP007243 & CG1489 & $\begin{array}{l}\text { Protein degradation, mem- } \\
\text { brane fusion, microtubule } \\
\text { severing, peroxisome bio- } \\
\text { genesis, signal transduction } \\
\text { and the regulation of gene } \\
\text { expression }\end{array}$ \\
\hline 271 & 1 & AAEL010487-RA conserved hypothetical protein & $4 \mathrm{e}-34$ & - & AGAP003487 & CG4666 & \\
\hline 272 & 2 & AAEL003006-RA 2-deoxyglucose-6-phosphate phosphatase & 0 & - & AGAP003372 & CG15441 & $\begin{array}{c}\text { L-2-haloacid dehalogenase } \\
\text { epoxide hydrolases and } \\
\text { phosphatases }\end{array}$ \\
\hline 273 & 1 & AAEL003006-RA 2-deoxyglucose-6-phosphate phosphatase & 0 & - & AGAP003372 & CG15441 & Cell signalling \\
\hline 275 & 1 & AAEL002833-RA cathepsin 1 & $2 \mathrm{e}-04$ & - & AGAP011828 & CG6692 & \\
\hline 276 & 1 & AAEL012903-RA sugar transporter & 0 & Supercont1.151 & AGAP007856 & - & $\begin{array}{l}\text { Membrane proteins re- } \\
\text { sponsible for the binding } \\
\text { and transport of various } \\
\text { carbohydrates }\end{array}$ \\
\hline 278 & 1 & AAEL008424-RB sodium/shloride dependent amino acid transporter & $4 \mathrm{e}-37$ & Supercont 1.487 & - & CG3252 & Symporter activity \\
\hline 279 & 1 & AAEL008188-RA 60S ribosomal protein L6 & 0 & - & AGAP001911 & CG11522 & \\
\hline 280 & 1 & AAEL005652-RA hypothetical protein & 0 & Supercont1.168 & - & - & \\
\hline 282 & 1 & AAEL006511-RA Anopheles stephensi ubiquitin & 0 & - & AGAP007927 & CG2960 & Ribosomal protein \\
\hline 283 & 2 & AAEL006169-RA cathepsin d & 0 & - & AGAP003277 & CG10104 & \\
\hline 284 & 1 & AAEL003147-RA conserved hypothetical protein & 0 & Supercont 1.468 & AGAP003565 & - & Zinc finger \\
\hline
\end{tabular}




\begin{tabular}{llc}
\hline Contig & n & vs. Ae. aegypti Liverpool strain transcripts \\
\hline 288 & 2 & AAEL013661-RA actin binding protein, putative \\
290 & 1 & AAEL006389-RA cathepsin 1 \\
291 & 2 & AAEL011758-RA peptidyl-prolyl cis-trans isomerase f, ppif
\end{tabular}

292
293
294

AAEL003431-RA proteasome subunit beta type 7,10 AAEL006885-RA 14-3-3 protein sigma, gamma, zeta, beta/alpha AAEL010843-RA conserved hypothetical protein

AAEL013533-RA conserved hypothetical protein AAEL010821-RA 60S acidic ribosomal protein P0 AAEL010943-RA conserved hypothetical protein

\section{AAEL004322-RA hypothetical protein \\ No hits found}

AAEL000084-RA elongin b ubiquitin

AAEL012200-RA protein kinase C inhibitor, putative

AAEL000284-RA conserved hypothetical protein

AAEL009829-RA ARL3, putative

AAEL007173-RC conserved hypothetical protein

AAEL004783-RA ornithine decarboxylase antizyme vs. Liverpool strain genomic supercontigs

vs. Anopheles gambiae

AGAP000235

AGAP012577

AGAP000462

AGAP007643

AGAP006459

AGAP008001

AGAP003592

AGAP003734

AGAP003154

AGAP006353

AGAP005673

AGAP006688

AGAP004868

AGAP010131 vs. Drosophila melanogaster

Function

Thymosin beta-4-inhibit actin polymerization

Peptidyl-prolyl cis-trans isomerase, cyclophilin type-protein folding by

catalyzing the cis-trans isomerization of proline imidic peptide bonds in oligopeptides

CG12161

CG17870

Translation initiation factor-

directing the ribosome

to the proper start site of translation

Ribosomal protein S8E

Cellular retinaldehyde-binding/triple function-visual cycle enzymes

CG6448

CG4204

CG2862

CG9643

CG33162

CG5174
Protein processing

Histidine triad

protein-nucleotide-binding proteins

SAM (and some other nucleotide) binding motif ADP-ribosylation factorvesicle biogenesis in intracellular traffic

Tumor protein D52-signal

$$
\text { eration }
$$

Ornithine decarboxylase antizyme-polyamine synthesis transduction and cell prolif- 


\begin{tabular}{|c|c|c|c|c|c|c|c|}
\hline Contig & $\mathrm{n}$ & vs. Ae. aegypti Liverpool strain transcripts & $\mathrm{e}$ & $\begin{array}{l}\text { vs. Liverpool strain } \\
\text { genomic supercontigs }\end{array}$ & $\begin{array}{l}\text { vs. Anopheles } \\
\text { gambiae }\end{array}$ & $\begin{array}{l}\text { vs. Drosophila } \\
\text { melanogaster }\end{array}$ & Function \\
\hline 307 & 1 & AAEL004148-RA heat shock protein 70 (hsp70)-interacting protein & 0 & - & AGAP010188 & CG2720 & \\
\hline 308 & 1 & AAEL008425-RA conserved hypothetical protein & 0 & - & AGAP000832 & CG14899 & $\begin{array}{l}\text { Der1-like-proteolytic sys- } \\
\text { tem ER }\end{array}$ \\
\hline 309 & 1 & AAEL005207-RA neprilysin & $2 \mathrm{e}-77$ & Supercont 1.363 & AGAP009791 & CG5905 & $\begin{array}{l}\text { Peptidase } \mathrm{M} \text {, neutral zinc } \\
\text { metallopeptidases, zinc- } \\
\text { binding site-peptidases }\end{array}$ \\
\hline 310 & 1 & AAEL006533-RA Ets domain-containing protein & 1e-98 & Supercont 1.133 & AGAP009494 & CG2914 & $\begin{array}{l}\text { Sterile alpha motif/pointed- } \\
\text { induction or inhibition of } \\
\text { gene transcription }\end{array}$ \\
\hline 312 & 1 & AAEL001092-RA udp-glucose pyrophosphatase & 0 & - & AGAP004158 & CG31063 & $\begin{array}{c}\text { Nucleoside diphosphate } \\
\text { pyrophosphatase-glycogen } \\
\text { biosynthesis }\end{array}$ \\
\hline 313 & 1 & AAEL003125-RA acyl-coa dehydrogenase & 0 & - & AGAP006780 & CG6638 & $\begin{array}{l}\text { Beta-oxidation in mitochon- } \\
\text { dion }\end{array}$ \\
\hline 314 & 1 & AAEL011540-RA metalloproteinase, putative & $3 e-74$ & Percont1.894 & AGAP011475 & - & Peptidase \\
\hline 315 & 1 & AAEL003611-RA stearoyl-coa desaturase & $1 e-26$ & - & AGAP003050 & CG15531 & Fatty acid desaturases \\
\hline 316 & 1 & AAEL013407-RA catalase & 0 & - & AGAP004904 & CG6871 & \\
\hline 317 & 1 & AAEL004716-RB chromodomain helicase dna binding protein & e-141 & Supercont 1.352 & AGAP008698 & CG3733 & Histone H5 \\
\hline 318 & & No hits found & e-115 & Supercont 1.293 & - & - & \\
\hline 320 & 1 & AAEL004325-RA ribosomal protein L5 & 0 & - & AGAP009031 & CG17489 & \\
\hline 321 & 1 & AAEL002058-RA hypothetical protein & 0 & Supercont1.32 & AGAP000504 & - & \\
\hline 323 & 1 & AAEL009169-RA synaptotagmin, putative & $3 e-12$ & Supercont1.51 & AGAP003725 & CG6643 & $\begin{array}{l}\text { C2-signal transduction or } \\
\text { membrane trafficking }\end{array}$ \\
\hline 324 & 1 & AAEL011436-RA myosin xv & $2 e-23$ & Supercont 1.537 & AGAP005213 & CG2174 & \\
\hline 325 & 1 & AAEL010826-RA histone-lysine n-methyltransferase & e-133 & - & - & CG6476 & Nuclear protein SET \\
\hline 326 & 1 & AAEL005085-RA 60S ribosomal protein L30 & e-159 & - & AGAP003816 & CG10652 & \\
\hline 327 & 1 & AAEL003666-RA leukotriene a-4 hydrolase & 0.93 & - & AGAP009907 & CG10602 & $\begin{array}{c}\text { Leukotriene A-4 hydrolase/ } \\
\text { aminopeptidase }\end{array}$ \\
\hline 328 & 1 & AAEL012313-RA charged multivesicular body protein 5 & 0 & - & AGAP005100 & CG6259 & Snf7- \\
\hline 329 & 1 & AAEL012661-RA eukaryotic translation initiation factor & 0 & - & AGAP007668 & CG10881 & $\begin{array}{l}\text { RNA recognition motif- } \\
\text { implicated in regulation of } \\
\text { alternative splicing }\end{array}$ \\
\hline 330 & 1 & AAEL008473-RA cysteine-rich venom protein, putative & 0 & - & AGAP007583 & CG16995 & $\begin{array}{l}\text { Pathogenesis-related } \\
\text { proteins }\end{array}$ \\
\hline 333 & 1 & AAEL001964-RA protein serine/threonine kinase, putative & 0 & - & - & - & Cell signalling \\
\hline 334 & 1 & AAEL001513-RA wd-repeat protein & 0.97 & - & - & - & Cell signalling \\
\hline 335 & 1 & AAEL012925-RA carbon catabolite repressor protein & $4 e-29$ & - & - & - & $\begin{array}{c}\text { Endonuclease/exonuclease/ } \\
\text { phosphatase }\end{array}$ \\
\hline 336 & 1 & AAEL004278-RA conserved hypothetical protein & $3 e-09$ & - & - & - & \\
\hline
\end{tabular}




\begin{tabular}{|c|c|c|c|c|c|c|c|}
\hline Contig & $\mathrm{n}$ & vs. Ae. aegypti Liverpool strain transcripts & e & $\begin{array}{l}\text { vs. Liverpool strain } \\
\text { genomic supercontigs }\end{array}$ & $\begin{array}{l}\text { vs. Anopheles } \\
\text { gambiae }\end{array}$ & $\begin{array}{l}\text { vs. Drosophila } \\
\text { melanogaster }\end{array}$ & Function \\
\hline 337 & 1 & AAEL009278-RA conserved hypothetical protein & $\mathrm{e}-122$ & - & - & - & \\
\hline 338 & 1 & AAEL007845-RA rab5 & 0 & - & - & - & $\begin{array}{l}\text { Regulators of vesicle } \\
\text { biogenesis in intracellular } \\
\text { traffic }\end{array}$ \\
\hline 340 & 1 & AAEL002225-RA 5-oxoprolyl-peptidase, putative & $2 \mathrm{e}-72$ & - & - & - & $\begin{array}{l}\text { Peptidase } \mathrm{C} 15 \text {, pyroglu- } \\
\text { tamyl peptidase I }\end{array}$ \\
\hline 341 & 1 & AAEL009274-RA conserved hypothetical protein & 0 & - & - & - & \\
\hline 342 & 1 & AAEL010087-RA proteasome subunit alpha type & 0 & - & - & - & \\
\hline 343 & 1 & AAEL009507-RA glucose-6-phosphate 1-dehydrogenase & $7 e-65$ & - & - & - & \\
\hline 345 & 1 & AAEL009764-RB xaa-pro aminopeptidase & 0 & - & - & - & Peptidase M24 \\
\hline 346 & 1 & AAEL002260-RA conserved hypothetical protein & e-119 & - & - & - & \\
\hline 347 & 1 & AAEL006785-RB 60S ribosomal protein L18a & $5 e-28$ & - & - & - & \\
\hline 348 & 1 & AAEL010777-RA thioredoxin (TRX), putative & $\mathrm{e}-180$ & - & - & - & $\begin{array}{c}\text { Protein disulphide oxidore- } \\
\text { ductase }\end{array}$ \\
\hline 349 & 1 & AAEL010132-RA Pray For Elves, putative & $2 \mathrm{e}-76$ & Supercont 1.321 & - & - & $\begin{array}{c}\text { Leucine-rich repeat-protein- } \\
\text { protein interaction/nervous } \\
\text { system protein-protein } \\
\text { interaction/immunity/neuro- } \\
\text { nal connectivity }\end{array}$ \\
\hline 351 & 1 & AAEL002508-RA 26S protease regulatory subunit $6 \mathrm{a}$ & 0 & - & - & - & \\
\hline 352 & 1 & AAEL007293-RA camp-dependent protein kinase catalytic subunit & $\mathrm{e}-174$ & - & - & - & $\begin{array}{c}\text { Protein kinase-phosphor- } \\
\text { ylation }\end{array}$ \\
\hline 353 & 1 & AAEL014821-RB hypothetical protein & $8 \mathrm{e}-48$ & - & - & - & \\
\hline 355 & 1 & AAEL006087-RA conserved hypothetical protein & 0 & Supercont 1.1051 & - & - & \\
\hline 356 & 1 & AAEL001747-RA conserved hypothetical protein & 0 & - & - & - & \\
\hline 358 & 1 & AAEL001037-RA ribosomal rna methyltransferase & 0 & - & - & - & \\
\hline 361 & 1 & AAEL008789-RA apolipophorin-III, putative & 0 & - & - & - & \\
\hline 362 & 1 & AAEL009436-RA conserved hypothetical protein & $1 \mathrm{e}-17$ & - & - & - & \\
\hline 363 & 1 & AAEL005799-RA peptidyl-prolyl cis-trans isomerase g, ppig & 0 & - & - & - & $\begin{array}{l}\text { Peptidyl-prolyl cis-trans } \\
\text { isomerase, cyclophilin } \\
\text { type-protein folding by } \\
\text { catalyzing the cis-trans } \\
\text { isomerization of proline } \\
\text { imidic peptide bonds in } \\
\text { oligopeptides }\end{array}$ \\
\hline 364 & 1 & AAEL010012-RA gtp-binding protein sar1 & 0 & - & - & - & $\begin{array}{l}\text { Protein trafficking. They } \\
\text { may modulate vesicle bud- } \\
\text { ding and uncoating within } \\
\text { the Golgi apparatus }\end{array}$ \\
\hline
\end{tabular}




\begin{tabular}{|c|c|c|c|c|c|c|c|}
\hline Contig & $\mathrm{n}$ & vs. Ae. aegypti Liverpool strain transcripts & e & $\begin{array}{l}\text { vs. Liverpool strain } \\
\text { genomic supercontigs }\end{array}$ & $\begin{array}{l}\text { vs. Anopheles } \\
\text { gambiae }\end{array}$ & $\begin{array}{l}\text { vs. Drosophila } \\
\text { melanogaster }\end{array}$ & Function \\
\hline 365 & 1 & AAEL013756-RA zinc/iron transporter & 0 & - & - & - & \\
\hline 367 & 1 & AAEL013103-RA conserved hypothetical protein & $3 e-15$ & - & - & - & \\
\hline 369 & & No hits found & $6 e-37$ & Supercont 1.1330 & - & - & \\
\hline 370 & 1 & AAEL000615-RA hypothetical protein & 0 & - & - & - & \\
\hline 371 & 1 & No hits found & $\mathrm{e}-136$ & Supercont 1.880 & - & - & \\
\hline 373 & 1 & AAEL010801-RB conserved hypothetical protein & e-159 & - & - & - & \\
\hline 375 & 1 & AAEL008159-RA short-chain dehydrogenase & 0 & - & - & - & $\begin{array}{l}\text { Insect alcohol dehydroge- } \\
\text { nase family }\end{array}$ \\
\hline 378 & 1 & $\begin{array}{l}\text { AAEL009637-RA } \\
\text { cathepsin b }\end{array}$ & 0 & & & & \\
\hline 380 & 1 & AAEL007291-RA replication factor A, 14kD-subunit, putative & $4 \mathrm{e}-30$ & - & - & - & \\
\hline
\end{tabular}

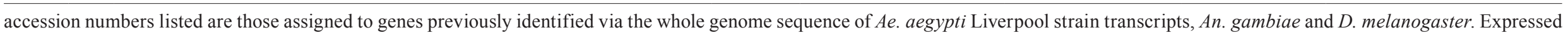
sequence tags (ESTs) identified in this study were deposited in dbEST under accessions. n: number of sequences used to make each contig. 